\title{
Convergence in Macroeconomics: Elements of the New Synthesis ${ }^{\dagger}$
}

\author{
By MiCHAEL WOODFORD*
}

\begin{abstract}
While macroeconomics is often thought of as a deeply divided field, with less of a shared core and correspondingly less cumulative progress than other areas of economics, in fact, there are fewer fundamental disagreements among macroeconomists now than in past decades. This is due to important progress in resolving seemingly intractable debates. In this paper, I review some of those debates and outline important elements of the new synthesis in macroeconomic theory. I discusses the extent to which the new developments in theory and research methods are already affecting macroeconomic analysis in policy institutions. (JEL A11, E00)
\end{abstract}

$\mathrm{H}$ as there been a convergence of views in macroeconomics? Of course, but there remains a wide spectrum of opinions on many issues and, perhaps even more striking, the dispersion of opinions regarding which topics are currently most interesting as subjects for further research is probably as wide as it has ever been. Nonetheless, I believe that there is less disagreement among macroeconomists about fundamental issues than there was in the past.

For example, in the 1960s, 1970s, and 1980s, macroeconomists were divided by controversies that related not only to judgments about the likely quantitative importance of particular economic mechanisms, or to the kind of policies that different scholars might advocate, but to basic questions of method (what kinds of models could reasonably be employed in macroeconomic analysis?; what kinds of empirical work could prove anything about the world?; and what kinds of questions could one hope to answer).

In the 1960s and early 1970s, the main division was between the neo-Keynesians and those in the monetarist school. This was not merely a dispute about whether the "IS curve" or "LM curve" was more interest elastic, or whether monetary policy or fiscal policy was more potent for purposes of aggregate demand management, as it was sometimes portrayed in undergraduate textbooks. Instead, the two schools had different conceptions of economics, and as a consequence, frequently argued against one another. The Keynesians sought to estimate structural econometric models that

\footnotetext{
* Department of Economics, Columbia University, 420 W. 118th Street, New York, NY 10027 (e-mail: michael. woodford@columbia.edu). Prepared for the session “Convergence in Macroeconomics?" at the annual meeting of the American Economics Association, New Orleans, January 4, 2008. I would like to thank Eduardo Engel, Marvin Goodfriend, and Julio Rotemberg for comments on an earlier draft.

${ }^{\dagger}$ To comment on this article in the online discussion forum visit the articles page at: http://www.aeaweb.org/articles.php?doi=10.1257/mac.1.1.267
} 
could be used to predict the short-run effects of alternative government policies. In this enterprise, they did not require the relations that constituted their models to be interpretable, other than relatively loosely, in terms of any economic theory, but rather argued for the empirical relevance of the models on the basis of their fit with aggregate time series. The monetarists were skeptical of this entire project. They denied that one could expect to reliably model short-run adjustment processes and instead emphasized the more robust predictions of economic theory about long-run outcomes. They doubted the usefulness of structural econometric models and preferred to base their positive and normative analyses on plots showing the co-movements of aggregate time series and on narrative accounts of economic developments. They scoffed at the aspiration to "fine tune" the business cycle using quantitative models.

In the late 1970s and the 1980s, the terms of debate shifted with the rise to prominence of the "New Classical" school and real business cycle theory. In some ways, the New Classicals might have seemed merely new recruits to the monetarist cause, defending many of the same theses, albeit with more modern weapons. ${ }^{1}$ Yet, their methodological position was quite different. Both the New Classical authors and the real business cycle theorists took the central task of macroeconomics to be the construction of structural models of short-run fluctuations, though they differed sharply from Keynesian modelers in their conception of the requirements for a coherent macroeconomic model, insisting on a rigorously formulated intertemporal generalequilibrium structure. The central division among macroeconomists ceased to be about whether one should try to precisely model short-run dynamics and came, instead, to be about whether it was more important to insist upon theoretical coherence in one's models, even if this meant doing without econometric validation (the position of the New Classical economists and real business cycle theorists), or to insist upon econometric testing, even if this meant using specifications little constrained by theory (the position of the Keynesian macroeconometric modelers).

In the context of this history, I believe that there has been a considerable convergence of opinion among macroeconomists over the past 10 or 15 years. While the problems of the field have not all been resolved, there are no longer such fundamental disagreements among leading macroeconomists about what kind of questions one might reasonably seek to answer, or what kinds of theoretical analyses or empirical studies should be admitted as contributions to knowledge. To some extent, this is because positions that were vigorously defended in the past have had to be conceded in the face of further argument and experience. But, to an important extent, it is also because progress in macroeconomic analysis has made it possible to see that the alternatives between which earlier generations felt it necessary to choose were not so thoroughly incompatible when understood more deeply. The cessation of methodological struggle within macroeconomics is due largely to the development of a new synthesis by Marvin Goodfriend and Robert G. King (1997), called "the

\footnotetext{
${ }^{1}$ Thus, James Tobin (1980) referred to the new school as "Monetarism Mark II." Alternatively, from a more recent perspective, N. Gregory Mankiw (2006) refers to monetarism as "the first wave of new classical economics."
} 
New Neoclassical Synthesis," that incorporates important elements of each of the apparently irreconcilable traditions of macroeconomic thought.

\section{Elements of the New Synthesis}

What do macroeconomists, at least those macroeconomists concerned with understanding the determinants of national income, inflation, and the effects of monetary and fiscal policy, ngenerally agree on? Here, I briefly list some of the most important examples of formerly contentious issues about which there is now fairly wide agreement.

First, it is now widely agreed that macroeconomic analysis should employ models with coherent intertemporal general-equilibrium foundations. These make it possible to analyze both short-run fluctuations and long-run growth within a single consistent framework. Of course, different model elements will be more important when addressing different questions, so that the complications from which one will frequently abstract will be different in the case of short-run and long-run issues. But it is now accepted that one should know how to render one's growth model and one's business-cycle model consistent with one another, in principle, on those occasions when it is necessary to make such connections. Similarly, microeconomic and macroeconomic analysis are no longer considered to involve fundamentally different principles, so that it should be possible to reconcile one's views about household or firm behavior, or one's view of the functioning of individual markets, with one's model of the aggregate economy, when one needs to do so.

In this respect, the methodological stance of the New Classical school and the real business cycle theorists has become the mainstream. But this does not mean that the Keynesian goal of structural modeling of short-run aggregate dynamics has been abandoned. Instead, it is now understood how one can construct and analyze dynamic general equilibrium models that incorporate a variety of types of adjustment frictions that allow these models to provide fairly realistic representations of both short-run and long-run responses to economic disturbances. In important respects, such models remain direct descendents of the Keynesian macroeconometric models of the early postwar period, though an important part of their DNA comes from neoclassical growth models as well. In light of this development, the conclusion by Robert E. Lucas, Jr., and Thomas J. Sargent $(1978,69)$ that not only were Keynesian macroeconometric models of the time lacking in "a sound theoretical or econometric basis" but, "there is no hope that minor or even major modification of these models will lead to significant improvement" must be regarded as having been premature.

I should also be clear that when I say it is now accepted that macroeconomic models should be general equilibrium models, I do not refer solely to the special case of models of perfect competitive equilibrium with fully flexible wages and prices. The dynamic stochastic general equilibrium (DSGE) models now used to analyze the short-run effects of alternative policies often involve imperfect competition in both labor markets and product markets, wages and prices that remain fixed for intervals of time rather than being instantaneously adjusted to reflect current market conditions, and an allowance for unutilized resources as a result of search and matching 
frictions. The insistence of monetarists, New Classicals, and early real business cycle theorists on the empirical relevance of models of perfect competitive equilibrium, a source of much controversy in past decades, is not what is now generally accepted. Instead, what is important is having general- equilibrium models, $n$ the broad sense of requiring that all equations of the model be derived from mutually consistent foundations, and that the specified behavior of each economic unit make sense given the environment created by the behavior of the others. At one time, Walrasian competitive equilibrium models were the only kind of models with these features that were well understood, but this is no longer the case.

Second, it is also widely agreed that it is desirable to base quantitative policy analysis on econometrically validated structural models. A primary goal of theoretical analysis in macroeconomics is to determine the data-generating process implied by one structural model or another in order to allow consideration of the extent to which the model's predictions match the properties of aggregate time series. Methods for the econometric estimation of structural models, and for stochastic simulation of such models under hypothetical policies, are a crucial part of the modern macroeconomist's tool kit. In this respect, the macroeconometric research program of the postwar Keynesians remains alive and well, given considerable new life by technical advances since the 1970s.

Modern macroeconometric modeling, exemplified by the work of Lawrence J. Christiano, Martin Eichenbaum, and Charles L. Evans (2005); David Altig et al. (2005); and Frank Smets and Raf Wouters (2003, 2007), represents a return to the ambitions of the postwar Keynesian modelers in at least two respects. First, the emphasis on the use of estimated structural models for policy analysis contrasts with the preference of many monetarists for drawing inferences about counterfactual policies from reduced-form empirical relations such as simple correlations between money growth and other variables. Second, the quest to develop models that are intended to provide a complete quantitative description of the joint stochastic processes by which a set of aggregate variables evolve, the parameters of which can then be estimated by direct comparison with the relevant time series, contrasts with the emphasis of first-generation "equilibrium business cycle theory" on stylized models that were intended to provide insight into basic mechanisms with no pretense of quantitative realism. It is now generally agreed that useful contributions to macroeconomic theory should be what King (1995) calls "quantitative theory."

Nonetheless, modern empirical macroeconomics differs from classic postwar macroeconometric modeling in deeper respects than the mere introduction of new approaches to estimation. In particular, a great deal more attention is given to the grounds for treating an econometric model as "structural" for purposes of a policy evaluation exercise. In the past, the specification of structural relations was often based only loosely on economic theory. The specific form of the relations was supposed to be dictated by the criterion of goodness of "fit," but, in practice, simple computational convenience played a large role in determining which kinds of relations one would attempt to "fit" to the data. (For example, one would assume purely backward-looking causal relations among a set of variables that happened to be part of one's dataset because of the convenience of estimating the coefficients of relations 
assumed to be of that form.) Now, instead, specifications that are intended to represent structural relations are derived from explicit decision problems of households or firms. Adjustment delays are allowed for, but these are assumed to be constraints that are taken into account by optimizing agents rather than arbitrary modifications of the optimal decision rule.

Relatively atheoretical methods, such as the estimation of unrestricted autoregressive or vector-autoregressive models, continue to be important in empirical macroeconomics, and have become more important since the 1980s. But a clearer distinction is now made between work that aims only at the characterization of data under a priori assumptions that are as weak as possible, and work that tries to represent structural relations. Pure data characterization is useful as a way of establishing facts that structural models should be expected to explain, but it is not a substitute for structural modeling. Instead, the two types of empirical work are complementary, two distinct parts of a single empirical research program that seek to develop empirically validated quantitative models that can be sensibly used in counterfactual policy analysis.

Modern macroeconomic modelers also depart from the early postwar literature in taking a more eclectic approach to the estimation of model parameters and testing of model predictions. One reason is that the modern style of structural model, with its deeper behavioral foundations, is not merely a prediction about the statistical properties of one particular type of data. Instead, it simultaneously makes claims about many things, both individual behavior and the behavior of aggregates and short-run dynamics and long-run averages, so that many different kinds of data are relevant, in principle, to model parameterization and to judging the model's empirical relevance. As a result, many different approaches to empirical analysis provide complementary perspectives on the quantitative realism of a given model. ${ }^{2}$

It sometimes appears to outsiders that macroeconomists are deeply divided over issues of empirical methodology. There continue to be, and probably will always be, heated disagreements about the degree to which individual empirical claims are convincing. A variety of empirical methods are used, both for data characterization and for estimation of structural relations, and researchers differ in their taste for specific methods, often depending on their willingness to employ methods that involve more specific a priori assumptions. But the existence of such debates should not conceal the broad agreement on more basic issues of method. Both "calibrationists" and the practitioners of Bayesian estimation of DSGE models agree on the importance of doing "quantitative theory." Both accept the importance of the distinction between pure data characterization and the validation of structural models, and both have a similar understanding of the form of model that can be properly regarded as structural.

Third, it is now widely agreed that it is important to model expectations as endogenous, and, in particular, that it is crucial in policy analysis to take into account the

\footnotetext{
${ }^{2}$ V. V. Chari and Patrick J. Kehoe (2007) refer to a "big-tent approach to data analysis" that "allows us to look for clues about the quantitative magnitudes of various mechanisms in a wide variety of sources using a wide variety of methods."
} 
way in which expectations should be different in the case that an alternative policy were to be adopted. This was, of course, the point of the celebrated Lucas (1976) critique of traditional methods of econometric policy evaluation. Because of sensitivity to this issue, it is now routine in positive interpretations of macroeconomic data and in normative analyses of possible economic policies to assume rational expectations on the part of economic decision makers in accordance with the methodology introduced by the New Classical literature of the 1970s.

Acceptance of the methodological precepts of the "rational expectations revolution" has not, however, meant acceptance of the view that stabilization policy is necessarily ineffective, as early commentary on the implications of that development often assumed. In modern DSGE models with sticky wages and/or prices, the fact that wage- and price-setting decisions are made on the basis of rational expectations has important consequences for the nature of the tradeoff between inflation and real activity, and for the way to think about the effects of policy. One cannot expect a simple answer about the effects of a given policy action, independent of whether the action is anticipated in advance or not, of whether the change in policy is expected to be persistent or not, and of what the policy authority announces about its policy intentions. Yet, these models typically imply that alternative systematic policies should lead to very different patterns of evolution of real activity, and that it should be quite possible, given sufficiently accurate real-time data, to design feedback rules for policy that achieves a greater degree of stabilization than less "activist" policies. As shown by John B. Taylor (1979) and a large subsequent literature, optimal control techniques (suitably adapted to deal with forward-looking structural relations) can be used to design ideal stabilization policies given such a model.

Fourth, it is now widely accepted that real disturbances are an important source of economic fluctuations. The hypothesis that business fluctuations can be largely attributed to exogenous random variations in monetary policy has few if any remaining adherents.

While studies such as those of Julio J. Rotemberg and Woodford (1997) or Christiano, Eichenbaum, and Evans (2005) estimate the effects of exogenous disturbances to monetary policy and assess the ability of structural models to account for these effects. This is because of the usefulness of this particular empirical test as a way of discriminating among alternative models and not because of any assertion that such disturbances are a primary source of aggregate variability. In fact, Altig et al. (2005) conclude that monetary policy shocks (identified by their VAR) account for only 14 percent of the variance of fluctuations in aggregate output at business cycle frequencies. Smets and Wouters (2007) find that monetary policy shocks account for less than 10 percent of the forecast error variance decomposition for aggregate output at any horizon.

By "real disturbances," I do not mean solely the "technology shocks" emphasized by the real business cycle theory of the 1980s. Modern empirical DSGE models, like that of Smets and Wouters, include a variety of types of disturbances to technology, preferences, and government policies (including fiscal shocks), and part of the variability in aggregate time series is attributed to each of these types of shocks. 
Technology shocks of one type or another are typically among the more important disturbances, however 3

More generally, the traditional Keynesian view of business cycles, according to which fluctuations are caused by a variety of types of real disturbances that affect economic activity solely through their effects on aggregate demand while aggregate supply evolves as a smooth trend, is no more confirmed by the modern models than is the pure monetarist view. While empirical DSGE models like that of Smets and Wouters (2007) do allow one to speak meaningfully of short-run departures from the "equilibrium" or "natural" level of real activity, that "natural rate of output" is not at all a smooth trend, and the disturbances that result in temporary departures from the natural rate typically also shift the natural rate.

At the same time, the claim that purely monetary disturbances are not the main source of business fluctuations does not imply that monetary policy is irrelevant in explaining such fluctuations. Empirical DSGE models with sticky wages, sticky prices, "sticky information," or some combination of these frictions, generally imply that the equilibrium effects of real disturbances depend substantially on the character of systematic monetary policy, that is, on the nature of the consistent feedback from aggregate conditions to central bank policy. Hence, the character of historical monetary policy still plays an important role in the explanation of observed business cycle patterns, and there remains an important degree of scope, at least in principle, for improved stabilization through the design of an appropriate monetary policy. While there is not agreement yet on the degree to which the greater stability of the United States and other economies in recent decades can be attributed to improvements in the conduct of monetary policy, the hypothesis that monetary policy has become conducive to stability, for reasons argued by Taylor, among others, is certainly consistent with the general view of business fluctuations presented by currentgeneration empirical DSGE models.

Fifth, monetary policy is now widely agreed to be effective, especially as a means of inflation control. The fact that central banks can control inflation if they want to (and are allowed to) can no longer be debated after the worldwide success of disinflationary policies in the 1980s and 1990s. It is also widely accepted that it is reasonable to charge central banks with the responsibility of keeping the inflation rate within reasonable bounds.

In this respect, the monetarist school has won an important debate with the postwar Keynesians. But this does not mean that variations in real activity, in capacity utilitization, and in other determinants of supply costs are not still viewed as important proximate causes of changes in the general level of prices. The Phillips curve is alive and well in current vintage empirical DSGE models, and a recent extensive literature has documented the degree to which the evolution of measures of real

\footnotetext{
${ }^{3}$ Altig et al. (2005) consider two types of technology shocks, a "neutral" shock and an investment-specific shock, and conclude that together these account for 28 percent of the variance of aggregate output at business cycle frequencies. In the estimated DSGE model of Smets and Wouters (2007), the corresponding two shocks account for about half of the GDP forecast error variance at a 10-quarter horizon.
} 
marginal cost can explain variations in the inflation rate -4 But it is now understood that neither the theoretical plausibility nor the empirical success of such models implies that inflation is determined by factors over which monetary policy has little influence. Not only is a Phillips curve in itself incomplete as a model of inflation (as it is merely a relation among endogenous variables), but the structure of general equilibrium models implies that household and firm behavior alone can, at most, determine the structure of relative prices rather than the absolute level of (monetary) prices, so that it must be government policy that supplies the "nominal anchor" if one is to exist.

Nor does accepting that monetary policy is the ultimate determinate of the general level of prices mean that it is necessary to understand prices as being determined by the quantity of money, and still less that inflation control requires careful monitoring of money supply measures. Monetary policy need not be identified with control of the money supply. And at most of the central banks with explicit commitments to an inflation target, monetary aggregates play little if any role in policy deliberations. Many empirical DSGE models, such as the Smets-Wouters model, make no reference to money, though they include an equation describing monetary policy and imply that the specification of that equation matters a great deal for the dynamics of both nominal and real variables.

\section{Remaining Disagreement}

While the study of business fluctuations is no longer driven by the kind of disagreements about the foundations of macroeconomic analysis that characterized the decades following World War II, important differences in methodological orientation remain among macroeconomists. Probably the most obvious divisions concern the importance attached, by different researchers, to work aspiring to "pure science" relative to work intended to address applied problems. This leads to differing evaluations of the degree of progress recently achieved in the field, which might suggest to outside observers that the foundations of the subject remain fundamentally contested, even though, as I have argued above, there are not really alternative approaches to the resolution of macroeconomic issues any longer.

One hears expressions of skepticism about the degree of progress in macroeconomics from both sides of this debate, from those who complain that macroeconomics is not concerned enough with scientific rigor and from those who complain that the field has been exclusively concerned with it. Some protest that the current generation of empirical DSGE models, mentioned above as illustrations of the new synthesis in methodology, have not been validated with sufficiently rigorous methods to be used in policy analysis (e.g., Chari, Kehoe, and Ellen R. McGrattan, 2008). Proponents of this view do not typically assert that some other available model would be more

\footnotetext{
${ }^{4}$ For reviews of this literature, see, among others, Jordi Galí, Mark Gertler, and J. David Lopez-Salido (2005), Argia M. Sbordone (2005), and Eichenbaum, and Jonas D. M. Fisher (2007).

${ }^{5}$ See Woodford (2008) for further discussion of the role of monetary aggregates in current vintage DSGE models for monetary policy analysis.
} 
reliable for that purpose. Instead, they argue that scholars with intellectual integrity have no business commenting on policy issues.

Lest there be confusion on this point, I should clarify that in asserting the existence of convergence in methodology, I do not mean to claim that all important theoretical and empirical issues in macroeconomics have been resolved. There is as yet little certainty about how best to specify an empirically adequate model of aggregate fluctuations. While efforts such as those of Christiano, Eichenbaum, and Evans (2005) or Smets and Wouters $(2003,2007)$ are encouraging, it would be foolish to claim that these models represent settled truth. Work in this vein is sufficiently new that one can hardly be surprised if, a decade from now, the best available models for use in policy analysis differ from these in important (though as yet unforeseeable) respects.

This does not mean that using such models as a basis for counterfactual policy simulations involves doubtful claims about the empirical validity of the models. Policy decisions must be constantly made despite policymakers' uncertainty about the precise effects of alternative choices. Even if one restricts the aims of policy (say, to a concern purely with inflation stabilization), difficult decisions must be made as to how to employ the available instruments of policy in the service of that goal. One can only base policy advice on provisional models, unless one is willing to allow policy to be made on even more ill-informed grounds. Of course, honest advice will be open about the places where there are obvious grounds for uncertainty about the provisional conclusions obtained from currently available models, and prudent policy decisions will seek to be robust to possible errors resulting from reliance on a faulty model. Questions about the robustness of the conclusions from policy analyses can be, and are, addressed within the current mainstream paradigm for macroeconomic analysis. Andrew Levin et al. (2005) provides a good example.

Nor is it convincing to suggest that improved policy advice might be obtained more reliably by devoting current research efforts to the clarification of "first principles" of macroeconomic theory, in the expectation that progress in the understanding of fundamental theory should eventually eliminate uncertainty about policy issues as well. While research aimed purely at theoretical clarification can be valuable, there is little reason to expect that the issues clarified will be the ones that matter for the improvement of policy, unless researchers directly address questions of public policy in their work, or at least address questions raised by the literature that analyzes policy issues.

In his paper, Mankiw $(2006,44)$ criticizes the current state of macroeconomics from the opposite perspective of the one just discussed. In Mankiw's view, since the 1970s, too much stress has been placed on the development of macroeconomics as a science with clear, conceptual foundations, and too little on macroeconomics as a branch of engineering, a body of lore about how to solve problems. As a result, he argues the conceptual developments of the past several decades have "had little impact on practical macroeconomists who are charged with the messy task of conducting actual monetary and fiscal policy." In this respect, he asserts all of the different, recent currents of thought among academic macroeconomists have equally failed. 
For example, Mankiw states that the models used for quantitative policy analysis in policy institutions like the Federal Reserve "are the direct descendents of the early modeling efforts of Klein, Modigliani, and Eckstein. Research by new classicals and new Keynesians has had minimal influence on the construction of these models" (Mankiw 2006, 42). But this is a misleading picture of the current state of affairs. It is true that the modeling efforts of many policy institutions can be reasonably seen as an evolutionary development within the macroeconometric modeling program of the postwar Keynesians. Thus, if one expected, with the early New Classicals, that adoption of the new tools would require building from the ground up, one might conclude that the new tools have not been put to use. But in fact they have been put to use, only not with such radical consequences as had once been predicted.

The Fed's current main policy model, the FRB/US model, was developed in the mid-1990s, before the recent renaissance of research on empirical DSGE models, but it incorporated many insights from the research literature of the 1970s and 1980s. As Flint Brayton et al. (1997) explained, it departed sharply from the previous generation of Federal Reserve Board models in giving much more attention to modeling the endogenous evolution of expectations and allowed model simulations to be conducted under an assumption of model-consistent (or rational) expectations, among other possibilities. The modelers also gave much more attention to ensuring that the model implied long-run dynamics consistent with an equilibrium model. For example, that the dynamics of both government debt and the external debt satisfy transversality conditions. Finally, adjustment dynamics were modeled not by simply adding arbitrary lags to structural relations, or even by ad hoc "partial adjustment" dynamics, but on the basis of dynamic optimization problems for the decision makers that incorporated explicit (though flexibly parameterized) adjustment costs.

Around the same time, new macroeconomic models were introduced at other central banks, such as the Bank of Canada's Quarterly Projection Model (Donald Coletti et al. 1996) and the Reserve Bank of New Zealand's Forecasting and Projection System (Richard Black et al. 1997), that were similarly modern in their emphasis on endogenous expectations and long-run dynamics consistent with an equilibrium model. These were not mere research projects, but models used for practical policy deliberations under the "forecast targeting" approach to monetary policy employed by both central banks beginning in the 1990s.

In the decade since, as the scholarly literature has devoted more attention to the development of models that are both theoretically consistent and empirically tested, the rate at which ideas from the research literature are incorporated into modeling practice in policy institutions has accelerated, with forecast-targeting central banks often playing a leading role. Examples of the more theoretically ambitious recent projects include the International Monetary Fund's Global Economy Model (Tamim Bayoumi et al. 2004), the Swedish Riksbank's RAMSES (Malin Adolfson et al. 2007), the European Central Bank's New Area-Wide Model (Kai Christoffel, Guenter Coenen, and Chris Warne 2007), and the Norwegian Economic Model (NEMO) under development by the Norges Bank (Leif Brubakk et al. 2006). All of these are coherent DSGE models reflecting the current methodological consensus 
discussed above, and matched to data through calibration or Bayesian estimation 6 And they are also all models developed by policy institutions for use in practical policy analysis?

Mankiw also states that central bankers find no use for modern developments in macroeconomics in their thinking about the economy and the decisions they face. As evidence, he cites the memoir of former Federal Reserve Governor Larry Meyer, saying that "Meyer's analysis of economic fluctuations and monetary policy is intelligent and nuanced, but it shows no traces of modern macroeconomic theory. It would seem almost completely familiar to someone who was schooled in the neoclassical-Keynesian synthesis that prevailed around 1970 and has ignored the scholarly literature ever since" (Mankiw 2006, 40). This does not sound like Larry Meyer the Federal Reserve governor to me, though like Harvard professors, he probably adopts a simpler manner when addressing the general public than when addressing his peers. Mankiw's interpretation also assumes, yet again, that acceptance of any part of the scholarly literature since 1970 would require thorough repudiation of pre-1970 ways of thinking. This is not so 8

In any event, it is hard to see how anyone could say this of the current members of the Federal Open Market Committee. The speeches of Ben S. Bernanke and other current governors and Federal Reserve Bank presidents are often laced with footnotes to the recent research literature. When the Fed recently introduced a new policy of discussing the quantitative forecasts of the FOMC members as part of the Committee's published minutes, Governor Frederic S. Mishkin explained the policy change to the public in a speech titled "The Federal Reserve's Enhanced Communication Strategy and the Science of Monetary Policy" (Mishkin 2007). This suggests to me the "disconnect" between the science of macroeconomics and the engineering side is not as great as Mankiw claims?

There remains, of course, a great deal for macroeconomists to be humble about, as Mankiw urges. The reduced level of dissension within the field does not mean that we have an adequate understanding of the problems addressed by it. One can still hope for much more progress, and competition among contending approaches and hypotheses will almost inevitably be part of the process through which such progress can occur. But the current moment is one in which prospects are unusually bright for progress with lasting consequences, due to the increased possibility of productive dialogue between theory and empirical work on the one hand, and between theory and practice on the other.

\footnotetext{
${ }^{6}$ RAMSES and the New Area-Wide Model are estimated models. The teams responsible for GEM and NEMO have indicated an intention to estimate their models using Bayesian methods as well, though only calibrated versions of the models are in use at present.

${ }^{7}$ There are also a great many other methodologically ambitious modeling projects underway within the research staffs of policy institutions including the Federal Reserve System. Here, I have mentioned only models that are already being used, or have clearly been developed to be used, in policy analysis by the institution responsible for developing the model.

${ }^{8}$ For the extent to which aspects of the conventional wisdom circa 1970 have been repudiated by practicing central bankers, and the role of the academic literature in this development, see Goodfriend (2007). In Goodfriend's characterization, "the story is one of mutually reinforcing advances in theory and practice" (Goodfriend 2007, 57).

${ }^{9}$ For further comment on Mankiw's argument, see David Warsh (2006).
} 


\section{REFERENCES}

Adolfson, Malin, Stefan Laséen, Jesper Lindé, and Mattias Villani. 2007. "RAMSES: A New General Equilibrium Model for Monetary Policy Analysis." Sveriges Riksbank Economic Review, 2007(2): 5-39.

Altig, David, Lawrence Christiano, Martin Eichenbaum, and Jesper Lindé. 2005. "Firm-Specific Capital, Nominal Rigidities, and the Business Cycle." National Bureau of Economic Research Working Paper 11034.

Bayoumi, Tamim A., Douglas Laxton, Hamid Faruqee, Ben Hunt, Philippe D. Karam, Jaewoo Lee, Alessandro Rebucci, and Ivan Tchakarov. 2004. "GEM: A New International Macroeconomic Model.” International Monetary Fund Occasional Paper 239.

Black, Richard, Vincenzo Cassino, Aaron Drew, Eric Hansen, Benjamin Hunt, David Rose, and Alasdair Scott. 1997. "The Forecasting and Policy System: The Core Model." Reserve Bank of New Zealand Research Paper 43.

Brayton, Flint, Andrew Levin, Ralph Tryon, and John Williams. 1997. "The Evolution of Macro Models at the Federal Reserve Board." Carnegie-Rochester Conference Series on Public Policy, 47(1): 43-81.

Brubakk, Leif, Tore Anders Husebo, Junior Maih, Kjetil Olsen, and Magne Ostnor. 2006. "Finding NEMO: Documentation of the Norwegian Economy Model." Norges Bank Staff Memo 2006/6. http://www.norges-bank.no/templates/pagelisting 51409.aspx.

Chari, V. V., and Patrick J. Kehoe. 2007. "The Heterogeneous State of Modern Macroeconomics: A Reply to Solow." National Bureau of Economic Research Working Paper 13655.

-Chari, V. V., Patrick J. Kehoe, and Ellen R. McGrattan. 2008. "New Keynesian Models Are Not Yet Useful for Policy Analysis." American Economic Journal: Macroeconomics, 1(1): 242-266.

-Christiano, Lawrence J., Martin Eichenbaum, and Charles L. Evans. 2005. "Nominal Rigidities and the Dynamic Effects of a Shock to Monetary Policy." Journal of Political Economy, 113(1): 1-45.

Christoffel, Kai, Guenter Coenen, and Chris Warne. 2007. "Conditional versus Unconditional Forecasting with the New Area-Wide Model." Unpublished.

Coletti, Donald, Benjamin Hunt, David Rose, and Robert Tetlow. 1996. "The Bank of Canada's New Quarterly Projection Model, Part 3. The Dynamic Model: QPM.” Bank of Canada Technical Report 75.

-Eichenbaum, Martin, and Jonas D. M. Fisher. 2007. "Estimating the Frequency of Price Re-optimization in Calvo-Style Models." Journal of Monetary Economics, 54(7): 2032-47.

Gali, Jordi, Mark Gertler, and J. David Lopez-Salido. 2005. "Robustness of Estimates of the Hybrid New Keynesian Phillips Curve." Journal of Monetary Economics, 52(6): 1107-18.

Goodfriend, Marvin. 2007. "How the World Achieved Consensus on Monetary Policy." Journal of Economic Perspectives, 21(4): 47-68.

Goodfriend, Marvin, and Robert G. King. 1997. "The New Neoclassical Synthesis and the Role of Monetary Policy." In NBER Macroeconomics Annual 1997, ed. Ben S. Bernanke and Julio J. Rotemberg, 231-83. Cambridge, MA: MIT Press.

King, Robert G. 1995. "Quantitative Theory and Econometrics." Federal Reserve Bank of Richmond Economic Quarterly, 81(3): 53-105.

Levin, Andrew, Alexei Onatski, John C. Williams, and Noah Williams. 2005. "Monetary Policy under Uncertainty in Micro-Founded Macroeconometric Models." NBER Macroeconomics Annual 2005, ed. Mark Gertler and Kenneth Rogoff, 229-87. Cambridge, MA: MIT Press.

Lucas, Robert E., Jr. 1976. "Econometric Policy Evaluation: A Critique." Carnegie-Rochester Conference Series on Public Policy, 1(1): 19-46.

Lucas, Robert E., Jr., and Thomas J. Sargent. 1978. "After Keynesian Macroeconomics.” In After the Phillips Curve: Persistence of High Inflation and High Unemployment. Federal Reserve Bank of Boston Conference Series 19, 49-72. Boston: Federal Reserve Bank of Boston.

-Mankiw, N. Gregory. 2006. "The Macroeconomist as Scientist and Engineer." Journal of Economic Perspectives, 20(4): 29-46.

Mishkin, Frederic S. 2007. "The Federal Reserve's Enhanced Communication Strategy and the Science of Monetary Policy.” Speech, M.I.T. Undergraduate Economics Association, Cambridge, MA, November 29, 2007. http://www.federalreserve.gov/newsevents/speech/mishkin20071129a.htm.

Rotemberg, Julio J., and Michael Woodford. 1997. "An Optimization-Based Econometric Framework for the Evaluation of Monetary Policy." In NBER Macroeconomics Annual 1997, ed. Ben S. Bernanke and Julio J. Rotemberg, 297-346. Cambridge, MA: MIT Press.

-Sbordone, Argia M. 2005. “Do Expected Future Marginal Costs Drive Inflation Dynamics?” Journal of Monetary Economics, 52(6): 1183-97. 
-Smets, Frank, and Raf Wouters. 2003. "An Estimated Dynamic Stochastic General Equilibrium Model of the Euro Area." Journal of the European Economic Association, 1(5): 1123-75.

-Smets, Frank, and Rafael Wouters. 2007. "Shocks and Frictions in US Business Cycles: A Bayesian DSGE Approach.” American Economic Review, 97(3): 586-606.

- Taylor, John B. 1979. "Estimation and Control of a Macroeconometric Model with Rational Expectations." Econometrica, 47(5): 1267-86.

Tobin, James. 1980. Asset Accumulation and Economic Activity: Reflections on Contemporary Macroeconomic Theory. Chicago: University of Chicago Press.

Warsh, David. 2006. “It Isn’t All in Adam Smith.” economicprincipals.com, December 10, 2006. http://www.economicprincipals.com/issues/06.12.10.html.

Woodford, Michael. 2008. "How Important is Money in the Conduct of Monetary Policy?" Journal of Money, Credit and Banking, forthcoming. 


\section{This article has been cited by:}

1. Maria Wimmer, Sabrina Scherer, Scott Moss, Melanie Bicking. 2014. Method and Tools to Support Stakeholder Engagement in Policy Development. International Journal of Electronic Government Research 8:3, 98-119. [CrossRef]

2. Amitava Krishna Dutt. 2013. Review. Challenge 56:5, 100-107. [CrossRef]

3. Lasse F. Henriksen. 2013. Economic models as devices of policy change: Policy paradigms, paradigm shift, and performativity. Regulation \& Governance n/a-n/a. [CrossRef]

4. P. Ormerod, B. Rosewell, P. Phelps. 2013. Inflation/unemployment regimes and the instability of the Phillips curve. Applied Economics 45:12, 1519-1531. [CrossRef]

5. Pedro de Araujo, Roisin O'Sullivan, Nicole B. Simpson. 2013. What Should be Taught in Intermediate Macroeconomics?. The Journal of Economic Education 44:1, 74-90. [CrossRef]

6. Waltraud Schelkle, Anke Hassel. 2012. The Policy Consensus Ruling European Political Economy: The Political Attractions of Discredited Economics. Global Policy 3, 16-27. [CrossRef]

7. Mohammed H. I. Dore, Rajiv G. Singh. 2012. The Role of Credit in the 2007-09 Great Recession. Atlantic Economic Journal 40:3, 295-313. [CrossRef]

8. Paul De Grauwe. 2012. Booms and busts in economic activity: A behavioral explanation. Journal of Economic Bebavior \& Organization 83:3, 484-501. [CrossRef]

9. John Quiggin. 2011. What Have We Learned from the Global Financial Crisis?. Australian Economic Review 44:4, 355-365. [CrossRef]

10. Grahame Thompson. 2011. SOURCES OF FINANCIAL SOCIABILITY. Journal of Cultural Economy 4:4, 405-421. [CrossRef]

11. Roland C. Winkler, Hans-Werner Wohltmann. 2011. On the (de) stabilizing effects of news shocks. Economics Letters . [CrossRef]

12. François Claveau. 2011. Evidential variety as a source of credibility for causal inference: beyond sharp designs and structural models. Journal of Economic Methodology 18:3, 233-253. [CrossRef]

13. Peter Howitt. 2011. What have central bankers learned from modern macroeconomic theory?. Journal of Macroeconomics . [CrossRef]

14. Joseph E. Stiglitz. 2011. RETHINKING MACROECONOMICS: WHAT FAILED, AND TO HOW REPAIR IT. Journal of the European Economic Association 9:4, 591-645. [CrossRef]

15. G. Argitis, Y. Dafermos. 2011. Finance, inflation and employment: a post-Keynesian/Kaleckian analysis. Cambridge Journal of Economics . [CrossRef]

16. P. De Grauwe. 2010. Top-Down versus Bottom-Up Macroeconomics. CESifo Economic Studies 56:4, 465-497. [CrossRef]

17. Christophe Gouel. 2010. AGRICULTURAL PRICE INSTABILITY: A SURVEY OF COMPETING EXPLANATIONS AND REMEDIES. Journal of Economic Surveys no-no. [CrossRef]

18. Ray C. Fair. 2010. Has macro progressed?. Journal of Macroeconomics . [CrossRef]

19. Ulrich Fritsche, Vladimir Kuzin. 2010. Analysing convergence in Europe using the non-linear single factor model. Empirical Economics . [CrossRef]

20. Grahame Thompson. 2010. The Global Regulatory Consequences of an Irrational Crisis: Examining 'Animal Spirits' and 'Excessive Exuberances'. Globalizations 7:1, 87-103. [CrossRef] 
21. Paul Ormerod. 2010. The current crisis and the culpability of macroeconomic theory. TwentyFirst Century Society 5:1, 5-18. [CrossRef]

22. Paul Ormerod. 2010. Risk, recessions and the resilience of the capitalist economies. Risk Management 12:1, 83-99. [CrossRef]

23. DERMOT HODSON, DEBORAH MABBETT. 2009. UK Economic Policy and the Global Financial Crisis: Paradigm Lost?. JCMS: Journal of Common Market Studies 47:5, 1041-1061. [CrossRef]

24. Olivier Blanchard. 2009. The State of Macro. Annual Review of Economics 1:1, 209-228. [CrossRef]

25. A. Leijonhufvud. 2009. Out of the corridor: Keynes and the crisis. Cambridge Journal of Economics 33:4, 741-757. [CrossRef] 